\title{
Forecasting Stock Prices of PT. Bank Negara Indonesia (Persero) Tbk., by Method (BOX-JENKINS)
}

\author{
Paiaman Pardede ${ }^{1}$ \\ paiaman_pardede@yahoo.com \\ Maurits Sipahutar ${ }^{2}$ \\ maurits_sipahutar08@yahoo.com \\ Parulian Naibaho ${ }^{3}$ \\ paruliannaibaho64@yahoo.com \\ 1)2)3)Fakultas Ekonomi Universitas Mpu Tantular
}

\begin{abstract}
The purpose of this study is to find the most appropriate model for predicting future stock prices, and the analytical tool used is ARIMA. In this study, the authors used the time series data of the share price of PT BNI (Persero) Tbk. from January 3, 2017, to June 28, 2019, consisting of 594 working days from the Investing.com database. The research found that the ARIMA model analysis $(3,1,3)$ is the most appropriate model for predicting the share price of PT. Bank Negara Indonesia (Persero) Tbk, with the equation model: Yt $=-6.331988+1.714721 Y t-1-0.149406 \mathrm{Yt}-2-1.72221 \mathrm{Y} \mathrm{t}-3+0.858083$ $\mathrm{Yt}-4+0.729283 \square \mathrm{t}-1-0.845787 \square \mathrm{t}-2-0.898101 \square \mathrm{t}-3$.
\end{abstract}

Keywords: Time Series, ARIMA, Box-Jenkins 


\section{INTRODUCTION}

The Capital Market is a place for long-term capital transactions, where demand represents securities issuing companies and offers represents by investors. The capital market has a significant role in economic activity. In countries adhering to a market economy system, the capital market has become a source of economic progress. It is because the capital market can be an alternative source of funds for companies that need funds. Recently, an indicator of a country's macro economy has also used the capital market. The country's economy reflects the fluctuating dynamics of the stock exchange index. That is why, in the publication of crucial indicators of the country, we often encounter data on the stock price index. When people want to assess the economic condition, they may look at the development of legal price index, inflation rate, current account balance, GDP growth, and other macroeconomic data. The main function of the capital market is to obtain funds for issuers from investors. Both capital markets are a means for people to invest in financial instruments such as stocks, bonds, mutual funds, etc. (Widoatmojo, 2015).

Firstly, a Central Bank of Indonesia established PT. Bank Negara Indonesia (Persero) Tbk. based on Government Regulation in place of Law No. 2 of 1946 dated 5 July 1946. The Republic of Indonesia government owns $60 \%$ of BNI shares, and the public, institutions, domestic and foreign individuals own $40 \%$. BNI is listed as the 4 th largest national bank in total assets, total loans, and total third party funds in Indonesia. In providing integrated financial services, BNI is supported by some subsidiary companies, namely Bank BNI Syariah, BNI Multifinance, BNI Sekuritas, BNI Life Insurance, and BNI Remittance. One model that is believed to be used to outperform daily stock trading is the Auto-Regressive Integrated Movin Average (ARIMA) developed by George Box and Gwilym Jenkins (1976). This model is suitable for forecasting daily stock price changes because it is by the technical analysis which uses time-series data from historical data as the basis for forecasting.

This study will discuss the problem of forecasting the share price of PT. Bank Negara Indonesia (Persero) Tbk. as follows:

1. Obtain the best forecasting model with the ARIMA Box Jenkins method on the share price data of PT. Bank Negara Indonesia (Persero) Tbk.

2. Obtain the results of forecasting the share price of PT. Bank Negara Indonesia (Persero) Tbk.

3. Have the percentage accuracy of the prediction index to the actual value of the shares of PT. Bank Negara Indonesia (Persero) Tbk.

\section{LITERATURE REVIEW}

Stock is one of the capital market instruments that are most in-demand by investors because it can provide an attractive rate of return. Shares are paper with comprehensible nominal value, company name, followed by the rights and obligations that have been explained to each holder, Fahmi (2012).

Sartono (2008) stated that in the capital market, the formation of share prices is the mechanism of supply and demand. If a stock is oversubscribed, the stock price tends to rise. Conversely, if the supply is excess, the share price tends to fall. The stock price fluctuates considerably every day. Observers believe the pattern of stock price movements is not only influenced by external factors but also influenced by the stock 
price yesterday or the previous day. Also, today's stock price affects the stock price tomorrow or the day after (Wing Wahyu Winarno). Modeling and forecasting using ARIMA are often associated with two names, namely G.E.P Box and G.M Jenkins. It is due to the second service of statistics uses the methodology of model identification, assessment, testing, and forecasting, making it easy to understand.

Box - Jenkins is a time-series model forecasting technique based on variable data behavior. Box - Jenkins is technically known as the autoregressive integrated moving average (ARIMA) model. The analysis is different from the structural model, the causal model, and the simultaneous model, where the equation of the model shows the relationship between the variables. The main reason for using the box - Jenkins technique is to examine the movements of economic variables such as exchange rates, stock prices, inflation, which are difficult to explain by economic theory. In his research at PT. Djoni Hatidja. TELKOM Tbk. The data used are secondary data from January 2010 to March 30, 2011, to predict stock prices from May to June 2011. The result showed that the model for the maximum stock price is ARIMA $(3,1,3)$. Grais S. Lilipaly in his 2014 research at PT BRI showed that the data from 2011 to October 2014 could be used to predict prices.

Box - Jenkins is a time-series model forecasting technique on the observed variable data behavior-based. Box - Jenkins is technically known as the autoregressive integrated moving average (ARIMA) model. This analysis is different from the structural model; both the causal model and the simultaneous model where the model equation shows the relationship between variables. The main reason for using the Box-Jenkins technique is because it examines the movement of economic variables such as exchange rates, stock prices, inflation, which economic theory finds hard to explain. In his research at PT. Djoni Hatidja. TELKOM Tbk. The data used are secondary data from January 2010 to March 30, 2011, to predict stock prices from May to June 2011. The results show that the model for the maximum stock price is ARIMA $(3,1,3)$. Grais S. Lilipaly's (2014) research at PT BRI showed that data is from 2- October 2014 could use to predict prices. Research from Bambang Hendrawan predicts IHSG, the ARIMA model has the best performance for predicting IHSG, the ARIMA is model $(2,1,2)$. Research from Reksanila and Atika nuraini (2010) entitled "Forecasting the Jakarta Islamic Index Stock Using the ARIMA Method in May July 2010" that the best ARIMA model obtained is ARIMA $(1,0,0)$.

\section{RESEARCH METHODOLOGY}

\section{Data and Data Sources}

This study uses secondary data such as stock price data from PT Bank Negara Indonesia (Persero) Tbk from January 2, 2017 - June 28, 2019, and obtained the database from investing.com. Box - Jenkins technique as a forecasting technique is different from most of the existing forecasting models. No specific assumption in this model about 
historical data from time series, but this method uses iterative to determine the best model. The selected model will then double-check with historical data whether it has described the data correctly. To obtain the best model will residue between the forecasting model and small historical data is distributed randomly and independently. Therefore, if the selected model cannot explain competently to determine repeatedly process the model. The Jenkins Box model consists of several models:

\section{Autoregressive (AR) Model}

The Autoregressive Model (AR) was first introduced by Yule in 1926 and developed by Walker in 1931. This model assumes that data in the previous period influenced the data in the current period.

The general form of the autoregressive model with the order $p$ abbreviated as AR (p) or ARIMA $(p, 0,0)$ stated as follows:

$X t=\mu^{\prime}+\varnothing_{1} X t_{-1}+\varnothing_{2} X t_{-2} \ldots+\varnothing p Z t-p+e t$

With:

$\mu$ ': a constant

$\varnothing \mathrm{p}$ : Parameters of the p-autoregressive model

e t: the error value in period $t$.

\section{Moving Average (MA)}

Moving Average represents the relationship between the observed value of successive current and past forecasting errors. The Moving Average (MA) model was first introduced by Slutzky in 1973, with the order q written MA (q) or ARIMA (0.0, q) and developed by Wadsworth in 1989. The MA (q) model is a model that predicts Xt as a function of the error of predicting $\mathrm{Xt}$ in the past. This model assumes that - each observation is formed from the weighted average deviation (disturbance) $q$ backward period (Nachrowi, 2006: 376). The general form of the moving average model with the order q, namely MA (q) or ARIMA $(0.0, q)$, is stated as follows:

$X t=\mu+e t-\varnothing_{1} e t-_{1} \quad-\varnothing_{2} e t-_{2}-\cdots-\varnothing^{e} t-q$

With:

$\mathrm{Xt}$ : stationary time series

M: constant et ${ }_{-1}$ : independent variable

Øq: q-th moving average parameter coefficient

et-q: error or random shock or error value at $t-q$ period

The difference between the moving average model and the autoregressive model lies in the type of independent variable. If the independent variable in the autoregressive model is the previous value (lag) of the dependent variable $(\mathrm{Xt})$ itself, then the moving average model as the independent variable is the residual value in the previous period. Orde of the MA value (given the q notation) is determined by the number of periods for the independent variable included in the model. Model Autoregressive Moving Average (ARMA) can combine into AR (p) and MA (q), thus assuming that the data for 
the current period is influenced by data in the previous period and the residual value in the previous period.

$\mathrm{Xt}=\mu+\varnothing_{1} \mathrm{Xt}-1_{1}+\ldots+\varnothing \mathrm{p} X \mathrm{t}-\mathrm{p}+$ at $-\varnothing_{1}$ at $-_{1}-\ldots-\varnothing \mathrm{q}$ at- $\mathrm{q}$

With:

$\mathrm{Xt}$ : stationary time series

$\mathrm{M}$ : constant Xt-p: independent variable

$\varnothing \mathrm{p}$ : the coefficient of the p-autoregressive parameter

at $_{-1}$ : independent variable

Øq: q-th moving average parameter coefficient

\section{Autregressive Integrated Moving Average (ARIMA)}

AR, MA, and ARMA models use the assumption that the resulting time series data is stationary. The time-series data are mostly non-stationary. The data set is stated to be stationary if the mean and variance values of the time series data do not change systematically over time, or some experts indicated that the mean and the variance are constant (Nachrowi, 2006). If the data is not stationary, the method used to make datastationary is the difference for data that is not stationary in the mean and the transformation process for data that is not stationary invariants. The Autoregressive Integrated Moving Average (ARIMA) model is used based on the assumption that time-series data used must be stationary, which means that the average variation of the data in question is constant. However, several things happen when data is not stationary. In overcoming the non-stationary data, a differencing process is carried out so that the data becomes stationary. Because the Autoregressive (AR), Moving Average (MA), Autoregressive Moving Average (ARMA) model is unable to explain the meaning of difference, a mixed model called Autoregressive Integrated Moving Average (ARIMA) or ARIMA ( $p, d, q)$ is used so that it becomes more effective in explaining the differencing process. In this mixed model, the stationary series is a linear function of the past value together with the present value and the past error. ARIMA model is usually denoted by ARIMA (p, d, q) which implies that the model uses $p$ dependent lag values, $\mathrm{d}$ differentiation process level, and q residual lag. The symbol of the previous model can also express with the ARIMA symbol, for example, MA (2) can be written in ARIMA $(0,0,2)$ AR $(1)$ can be written in ARIMA $(1,0,0)$ ARMA $(1,2)$ can be written with ARIMA $(1,0,2)$ and so on.

The following are the steps involved in choosing the ARIMA model, namely: The first step in the ARIMA process is identification. This step carries out to determine whether the observed data is stationary. If it is not stationary, do the differentiation process until the data is stationary. After that, make a correlogram data distribution to determine autoregressive order and moving average order. The selected order is time lag that is an autoregressive coefficient and significant partial autoregressive coefficient. Determination of the order (time lag) for AR and MA is done by trial and error. 
Therefore, the ARIMA model has more artistic elements than scientific elements (Gujarati, 2003). The following are the steps involved in choosing the ARIMA model, namely: The first step in the ARIMA process is identification. This step carries out to determine whether the observed data is stationary. If it is not stationary, do the differentiation process until the data is stationary. After that, make a correlogram data distribution to determine autoregressive order and moving average order. The selected order is time lag that is an autoregressive coefficient and significant partial autoregressive coefficient. Determination of the order (time lag) for AR and MA is done by trial and error. Therefore, the ARIMA model has more artistic elements than scientific elements (Gujarati, 2003). The significance of its estimation parameters the Akaike Information Criteria (AIC) value the Schwarz Information Criteria (SIC). The third step is to test the residual distribution. A good model is a model that has randomly distributed residuals (white noise). This test is performed by comparing the magnitude of the autocorrelation function (ACF) coefficient and the residual partial autoregressive function (PACF) coefficient obtained from the residual correlogram. If the ACF coefficient and the PACF coefficient are not significant (the coefficient value is smaller than the critical value), then the model obtained is white noise, namely randomly distributed residuals. The fourth step is to forecast the value of the observed variables using the best model.

\section{RESULT AND DISCUSSION \\ Stationary Test}

Three analyzes perform to determine whether the data was stationary or not.

\section{Correlogram}

Table 1. Coreelogram

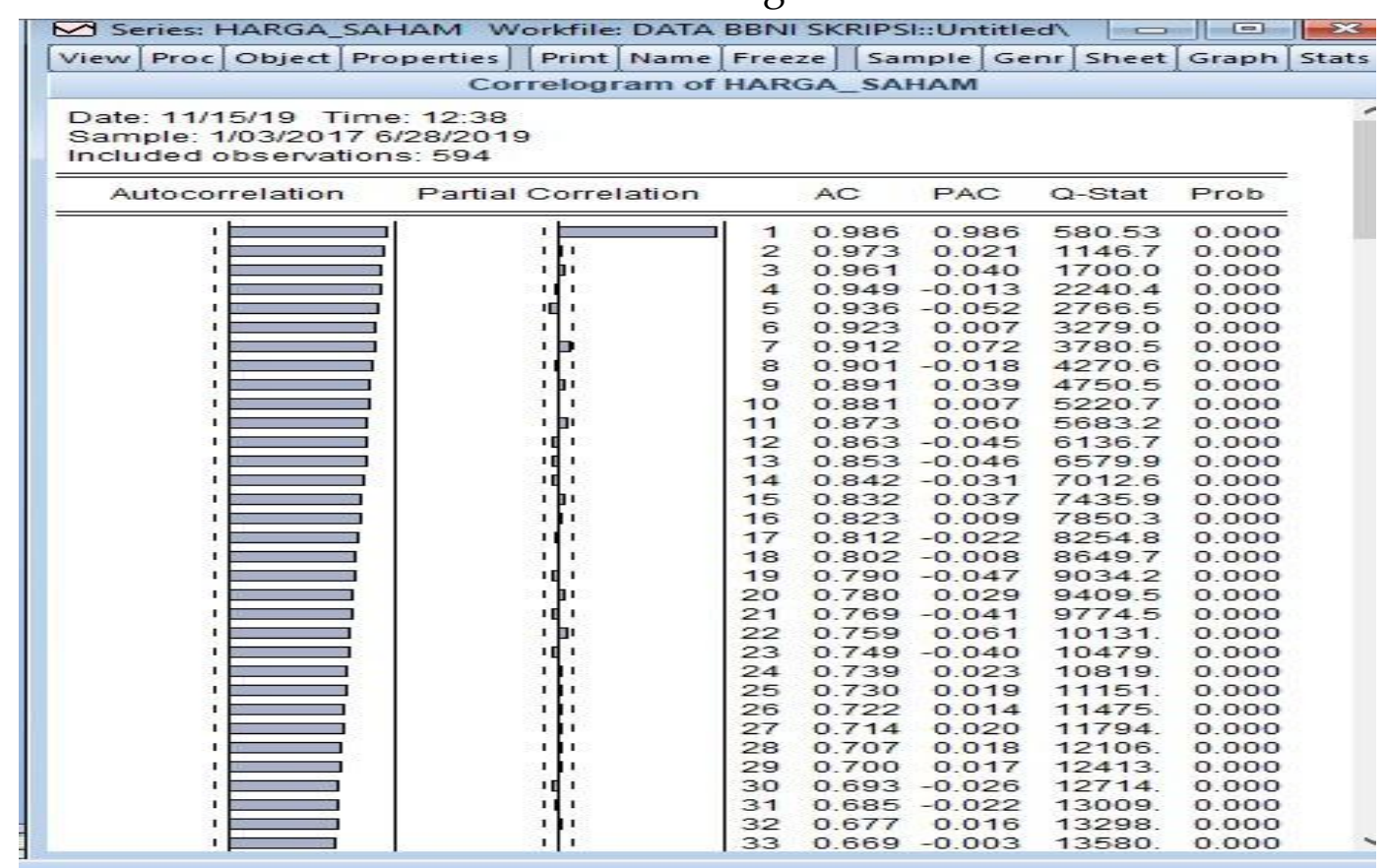


Table 1, the Correlogram (Yt) generated by the Eviews program shows that the autocorrelation coefficient value is substantial. Meanwhile, all partial autocorrelation coefficients close to zero after the first lag indicates that the data is not stationary. ARIMA requires stationary data.

\section{Graphic}

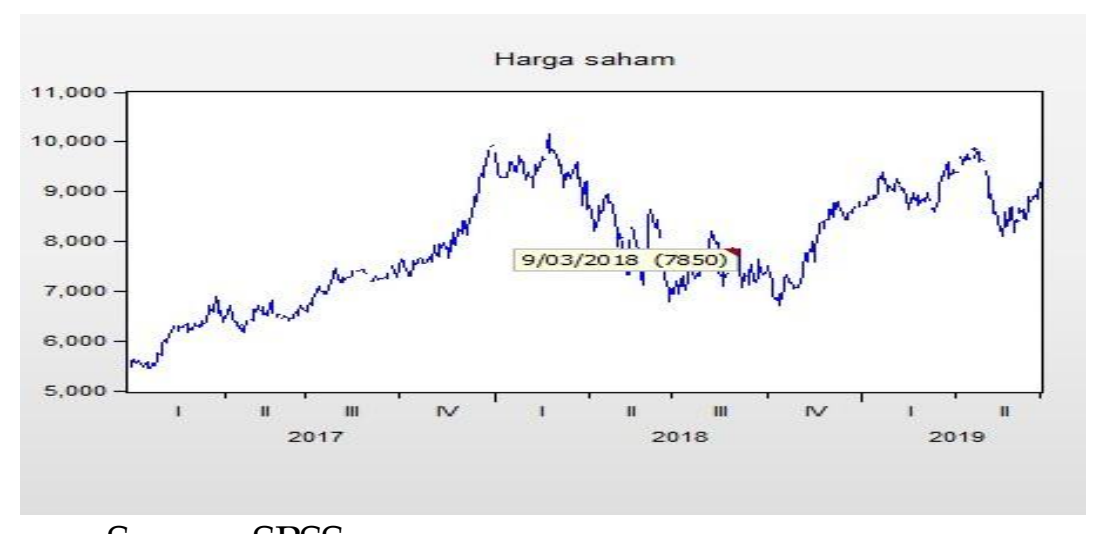

Source: SPSS

Figure 1. Graphical Test

The graph above shows that the lines tend not to be flat, it concludes that the PT.BNI stock price data for the period January 2017 - June 2019 is not stationary.

\section{Root Unit Test}

Table 2. Root Unit Test

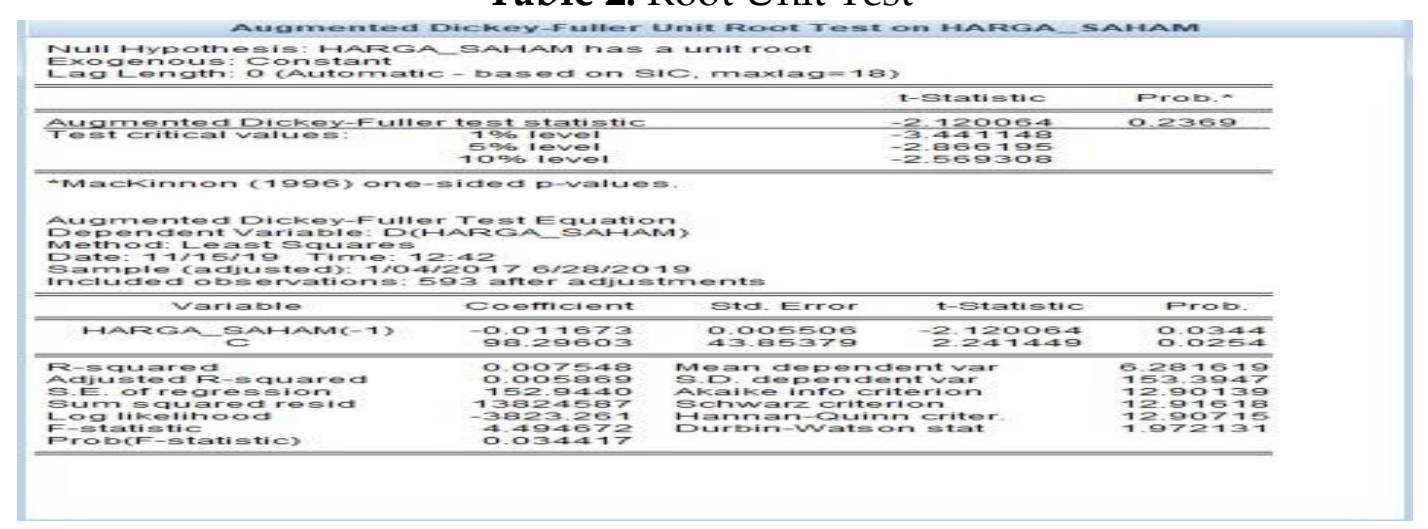

Source: SPSS

In table 1, the unit root test results showed that the value of $a=1 \%$ is -3.441148 , a $5 \%$ is -2.866195 , and $\alpha=10 \%$ is 2.569308 , much greater than the statistical value of $=2.120064$, indicating that the data is not stationary. The three analysis tools above both show the data is not stationary. Because the data is not stationary, the next step is to make the data stationary by first differentiating one lag the result follow: 


\section{Test Unit Different Root 1}

Table 3. Test Result Unit Different Root 1

\begin{tabular}{|c|c|c|c|c|}
\hline \multicolumn{5}{|c|}{ Augmented Dickey-Fuller Unit Root Test on D(HARGA_SAHAM) } \\
\hline \multicolumn{5}{|c|}{$\begin{array}{l}\text { Null Hypothesis: D(HARGA_SAHAM) has a unit root } \\
\text { Exogenous: Constant } \\
\text { Lag Length: O (Automatic-based on SIC, maxlag=18) }\end{array}$} \\
\hline & & & t-Statistic & Prob* \\
\hline \multicolumn{3}{|c|}{$\begin{array}{c}\text { Augmented Dickey-Fuller test statistic } \\
\text { Test critical values: } \\
5 \% \text { level level } \\
10 \% \text { level }\end{array}$} & $\begin{array}{l}-24.07335 \\
-3.441167 \\
-2.866204 \\
-2.569313\end{array}$ & 0.0000 \\
\hline \multicolumn{5}{|c|}{$\begin{array}{l}\text { Augmented Dickey-Fuller Test Equation } \\
\text { Dependent Variable: D(HARGA-SAHAM,2) } \\
\text { Method:Least Squares } \\
\text { Date: } 1115 / 19 \text { Time: } 12: 47 \\
\text { Sample (adjusted): } 1 / 05 / 20176 / 28 / 2019 \\
\text { included observations: } 592 \text { after adjustments }\end{array}$} \\
\hline Variable & Coefficient & Sta. Error & t-Statistic & Prob. \\
\hline D(HARGA_SAHAM $(-1))$ & $\begin{array}{r}-0.993649 \\
6.044336\end{array}$ & $\begin{array}{l}0.041276 \\
6.316349\end{array}$ & $\begin{array}{r}-24.07335 \\
0.956935\end{array}$ & $\begin{array}{l}0.0000 \\
0.3390\end{array}$ \\
\hline $\begin{array}{l}\text { R-squared } \\
\text { Adjusted R-squared } \\
\text { S.E of regression } \\
\text { Sum squared resid } \\
\text { Log likelihood } \\
\text { F-Statistic } \\
\text { Prob(F-statistic) }\end{array}$ & $\begin{array}{r}0.495522 \\
0.494667 \\
153.5735 \\
13915050 \\
-3819.244 \\
579.5261 \\
0.000000\end{array}$ & $\begin{array}{l}\text { Mean depen } \\
\text { S.D. depend } \\
\text { Akaike info C } \\
\text { Schwarz crite } \\
\text { Hannan-Dui } \\
\text { Durbin-Wats }\end{array}$ & $\begin{array}{l}\text { identvar } \\
\text { dentvar } \\
\text { criterion } \\
\text { erion } \\
\text { inn criter. } \\
\text { son stat. }\end{array}$ & $\begin{array}{l}0.295608 \\
216.0367 \\
12.90961 \\
12.92442 \\
12.91538 \\
1.993284\end{array}$ \\
\hline
\end{tabular}

Source: SPSS

In the table of the results of the unit root test above, the value of $a=1 \%$ is -3.441148 , $a$ $5 \%$ is -2.866195 and $a=10 \%$ is 2.569308 , much smaller than the statistical value of $=-$ 24.07335. It shows that the data is stationary in the first difference. From the description of the correlogram above, it concludes that the data is stationary in the first difference $(d=1)$, so then, all analyses to be carried out in this study are analyzes at the first different level called ARIMA with $d=1(p, d=1, q)$.

\section{ARIMA Estimation}

To explain how to model and at the same time predict stock prices in the future, here is an explanation of the first few different ARIMA models, namely ARIMA $(1,1,1$,$) ,$ ARIMA (0,1,1,), ARIMA (1,1, 0,), ARIMA (2,1,0,), ARIMA $(0,1,2$,$) , ARIMA (1,1,2$,$) .$ ARIMA (2,1,1,). ARIMA (2,1,2,). ARIMA (0,1,3,). ARIMA (1,1,3,). ARIMA $(2,1,3$,$) .$ ARIMA (3,1,0,). ARIMA (3,1,1)). ARIMA (3,1,2,). ARIMA $(3,1,3$,$) . In obtaining the$ ARIMA models, the next step is to estimate the parameters of models that is to test the hypothesis for each coefficient parameter that each model has. 
PRIMANOMICS : JURNAL EKONOMI DAN BISNIS - VOL. 19. NO. 1 (2021)

Versi Online Tersedia di : https://jurnal.ubd.ac.id/index.php/ds

| 1412-632X (Cetak) | 2614-6789 (Online) |

\section{ARIMA Estimation $(2,1,3)$}

Table 4. Estimated ARIMA (123)

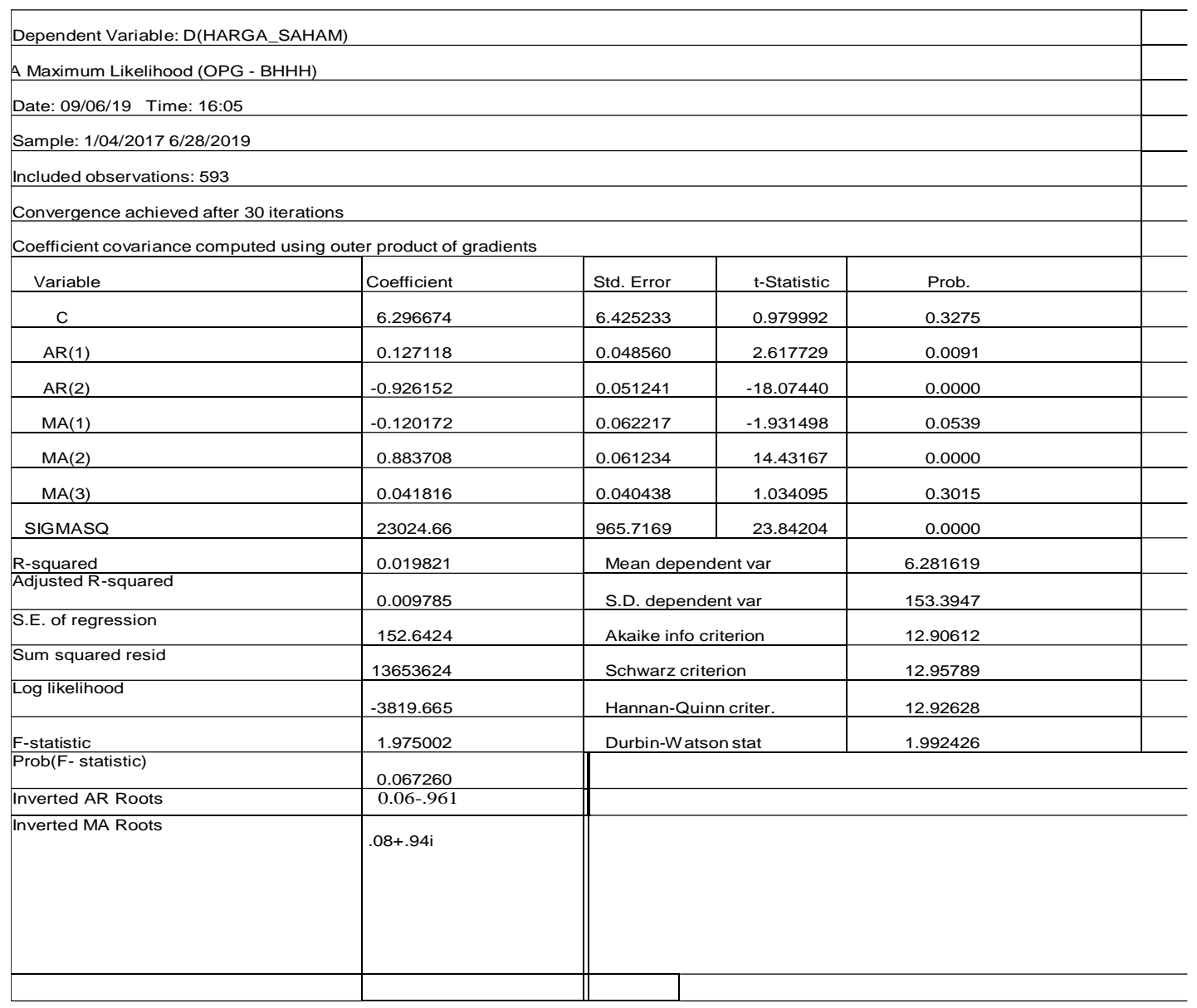

Source: SPSS

The results of the ARIMA table $(2,1,3)$ show that the variables C, AR (1), MA (1) MA (3) are not yet significant, while AR (2) and MA (2) are significant, and also R-Squared. It is still small. So it is necessary to experiment with replacing $\mathrm{p}$ and $\mathrm{q}$ starting from zero to 3 (three) for all ARIMA models, to find a better model by replacing the numbers in less good for $\mathrm{p}$ and $\mathrm{q}$ for all ARIMA models is tested. 


\section{ARIMA Estimation $(3,1,3)$}

Table 5. Estimated ARIMA (313)

\begin{tabular}{|c|c|c|c|c|}
\hline \multicolumn{5}{|c|}{$\begin{array}{l}\text { Dependent Variable: D(HARGA_SAHAM) } \\
\text { Method: ARMA Maximum Likelihood (OPG - BHHH) } \\
\text { Date: 09/06/19 Time: } 15: 45\end{array}$} \\
\hline \multicolumn{5}{|c|}{ Sample: 1/04/2017 6/28/2019 } \\
\hline \multicolumn{5}{|c|}{ Included observations: 593} \\
\hline \multicolumn{5}{|c|}{ Convergence not achieved after 500 iterations } \\
\hline \multicolumn{5}{|c|}{ Coefficient covariance computed using outer product of gradients } \\
\hline Variable & Coefficient & Std. Error & t-Statistic & Prob. \\
\hline $\mathrm{C}$ & 6.331988 & 6.462622 & 0.979786 & 0.3276 \\
\hline$A R(1)$ & -0.714721 & 0.124374 & -5.746562 & 0.0000 \\
\hline $\operatorname{AR}(2)$ & -0.864127 & 0.021348 & -40.47828 & 0.0000 \\
\hline$A R(3)$ & -0.858083 & 0.124515 & -6.891397 & 0.0000 \\
\hline $\mathrm{MA}(1)$ & 0.729283 & 0.107785 & 6.766114 & 0.0000 \\
\hline $\mathrm{MA}(2)$ & 0.845787 & 0.062896 & 13.44730 & 0.0000 \\
\hline $\mathrm{MA}(3)$ & 0.898101 & 0.126578 & 7.095242 & 0.0000 \\
\hline SIGMASQ & 22681.53 & 1626.736 & 13.94297 & 0.0000 \\
\hline R-squared & 0.034428 & \multicolumn{2}{|c|}{ Mean dependent var } & 6.281619 \\
\hline Adjusted R-squared & 0.022874 & \multicolumn{2}{|c|}{ S.D. dependent var } & 153.3947 \\
\hline S.E. of regression & 151.6302 & \multicolumn{2}{|c|}{ Akaike info criterion } & 12.90107 \\
\hline Sum squared resid & 13450149 & \multicolumn{2}{|c|}{ Schwarz criterion } & 12.96022 \\
\hline Log likelihood & -3817.166 & \multicolumn{2}{|c|}{ Hannan-Quinn criter. } & 12.92411 \\
\hline F-statistic & 2.979812 & \multicolumn{2}{|c|}{ Durbin-Watson stat } & 2.001047 \\
\hline Prob(F-statistic) & 0.004440 & & & \\
\hline Inverted AR Roots & $.07+.99 i$ & -.86 & & \\
\hline Inverted MA Roots & $.09-1.00 i$ & -.90 & & \\
\hline
\end{tabular}

Source: SPSS

The results of the ARIMA table (3,1,3) shows that the variables C, AR (1), AR (2), AR (3) MA (1), MA (2), and MA (3) are significant, and also R -Squared is better than before. 
PRIMANOMICS : JURNAL EKONOMI DAN BISNIS - VOL. 19. NO. 1 (2021)

Versi Online Tersedia di : https://jurnal.ubd.ac.id/index.php/ds | 1412-632X (Cetak) | 2614-6789 (Online) |

Table 6. Significance of Model Parameters

\begin{tabular}{|c|c|c|c|c|c|c|c|c|c|c|c|c|}
\hline & ARIMA & $\mathrm{C}$ & $\mathrm{a} 1$ & a2 & a3 & $b_{1}$ & $\mathrm{~b}_{2}$ & $b_{3}$ & SSR & AIC & SIC & \\
\hline \multirow[b]{2}{*}{1} & (1.1.1) & 6.2956 & .86256 & & & 0.89831 & & - & 1386007 & 12.9107 & \begin{tabular}{|l|l}
7 & 12.9403 \\
\end{tabular} & \multirow{2}{*}{\begin{tabular}{l|} 
Keterangan \\
3 AR(1) MA(1) \\
Sig C Non sig
\end{tabular}} \\
\hline & & $(0,3386)$ & $(0,000$ & & F & $(0,0000$ & & $F$ & & & & \\
\hline & ARIMA & 6.286064 & 0.0635 & 5 & F & - & - & - & 1392916 & 12.9123 & \begin{tabular}{|l|l|}
3 & 12.9344 \\
\end{tabular} & \multirow[b]{2}{*}{ on sig } \\
\hline 2 & $(1,1,0)$ & $(0,3218)$ & $(0,8684)$ & F & - & - & F & $F$ & & & & \\
\hline \multirow[b]{2}{*}{3} & ARIMA & 6.2866 & - & - & F & 0.00727 & - & - & 1392908 & \begin{tabular}{|l|l}
3 & 12.9122 \\
\end{tabular} & \begin{tabular}{|l|l|}
2 & 129344
\end{tabular} & \multirow[b]{2}{*}{ Non sig } \\
\hline & $(0,1,1)$ & $(0,3221)$ & - & - & - & $(0.8455)$ & - & - & & & & \\
\hline \multirow[b]{2}{*}{4} & ARIMA & 6.237764 & 0.006686 & 0.06366 & - & F & F & 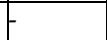 & 13872737 & 12.91162 & 12.94120 & \multirow{2}{*}{ Non sig } \\
\hline & $(2,1,0)$ & $(0,2948)$ & $(0,8599)$ & \begin{tabular}{|l|}
$(0.0659)$ \\
\end{tabular} & & - & - & - & & & & \\
\hline \multirow{2}{*}{5} & ARIMA & 6.238152 & 004187 & -063608 & & 0.010916 & & - & 13872717 & 12.91499 & 12.95197 & \multirow{2}{*}{ Non sig } \\
\hline & $(2,1,1)$ & $(0,2978)$ & $(0.9945)$ & $(0.0665)$ & & $(0.9857)$ & & - & & & & \\
\hline \multirow{2}{*}{6} & ARIMA & 6.240911 & & - & & 0.006655 & -.057292 & - & 13878687 & 12.91205 & 12.94163 & \multirow{2}{*}{ Non sig } \\
\hline & $(0,1,2)$ & $(0,2964)$ & & - & & $(0.8606)$ & $(0.0988)$ & - & & & & \\
\hline \multirow{2}{*}{7} & ARIMA & 6.240677 & 0.007544 & & & -.912758 & -.057358 & F & 13878680 & 12.91542 & 12.95240 & \multirow{2}{*}{ Non sig } \\
\hline & $(1,1,2)$ & $(0,2994)$ & $(0,9911)$ & - & - & $(0.9990)$ & $(0.1011)$ & - & & & & \\
\hline \multirow{2}{*}{8} & ARIMA & 6.247385 & 0.046352 & 0.89302 & & -.893021 & 0.834314 & & 13678828 & 12.90448 & 12.94884 & \multirow{2}{*}{\begin{tabular}{|l|} 
AR(1) MA(1) \\
Sig AR(2) \\
MA(2) NonSig
\end{tabular}} \\
\hline & $(2,1,2)$ & $(0,2994)$ & $(0,5269)$ & $(0,0000)$ & & $(0.4804)$ & $(0,0000)$ & F & & & & \\
\hline \multirow{2}{*}{9} & ARIMA & 6.240086 & & - & & 0.006888 & -.057336 & -.001555 & 13878663 & 12.91542 & 12.95240 & \multirow{2}{*}{ Non sig } \\
\hline & $(0,1,3)$ & $(0.2988)$ & & - & - & $(0.8560)$ & $(0.0986)$ & $(0.9679)$ & & & & \\
\hline \multirow[b]{2}{*}{10} & ARIMA & 6.234285 & .357802 & & - & 0.366730 & -.053214 & -039563 & 13874499 & 12.91849 & 12.96286 & \multirow{2}{*}{ Non sig } \\
\hline & $(1,1,3)$ & $(0.2990)$ & $(0.8085)$ & & - & $(0.8031)$ & $(0.1469)$ & $(0.6198)$ & & & & \\
\hline \multirow{2}{*}{11} & ARIMA & 6.296674 & 0.127118 & -926152 & & -.926152 & 0.883708 & 0.041816 & 13653624 & 12.90612 & 12.95789 & \multirow{2}{*}{$\begin{array}{l}\text { C Non Sig AR } \\
\text { (1) AR(2) } \\
\text { MA(2)Sig }\end{array}$} \\
\hline & $(2,1,3)$ & $(0.3275)$ & $(0.0091)$ & $(0,0000)$ & & $(0.0539)$ & $(0,0000)$ & \begin{tabular}{|l|}
$(0.3015)$ \\
\end{tabular} & & & & \\
\hline \multirow{2}{*}{12} & ARIMA & 6.238964 & 0.006816 & -036681 & 0.002096 & & [ & - & 13872676 & 1291499 & 12.95197 & \multirow{2}{*}{ Non sig } \\
\hline & $(3,1,0)$ & $(0.2987)$ & $(0.8573)$ & $(0.0662)$ & $(0.9569)$ & & & & & & & \\
\hline \multirow{2}{*}{13} & ARIMA & 6.231700 & -390956 & -060928 & -0.040114 & 0.396828 & F & - & 13869093 & 12.91811 & 12.96248 & \multirow{2}{*}{ Non sig } \\
\hline & $(3,1,1)$ & $(0.2972)$ & $(0.8348)$ & $(0.0959)$ & $(0.7203)$ & $(0.8230)$ & & & & & & \\
\hline & ARIMA & 6.297426 & 0.172600 & -931165 & 0.043129 & -.165972 & 0.889794 & & 13653890 & 12.90614 & 12.95790 & C Non sig \\
\hline & $(3,1,2)$ & $(0.3288)$ & $(0.0180)$ & $(0,0000)$ & $(0.3019)$ & $(0.0104)$ & $(0,0000)$ & & & & & $\begin{array}{l}\operatorname{AR}(1) \operatorname{AR}(2) \\
M A(1)\end{array}$ \\
\hline $1-$ & ARIMA & 6.33198 & -.714721 & -864127 & -0.858083 & 0.729283 & 0.845787 & 0.898101 & 13450149 & 12.90107 & 12.96022 & CNonsigAR(1 \\
\hline & $(3,1,3)$ & $(0.3276)$ & $(0,0000)$ & $(0,0000)$ & $(0,0000)$ & $(0,0000)$ & $(0,0000)$ & $(0,0000)$ & & & & MA(1) MA(2) \\
\hline
\end{tabular}

Source: SPSS

Based on table six the 15 ARIMA models shown, only five models are better than the other models even though they are imperfect, because of the 15 models the results are none of the models with all significant variables. However, in the research needs, from all the models that have been described, five models are considered to be better models, namely ARIMA $(1,1,1)$, ARIMA $(2,1,2)$, and ARIMA $(2,1,3)$, ARIMA $(3,1,2)$, ARIMA $(3,1,3)$ because there are already significant variables, while none of the other ARIMA variables are significant. Of the five good models, the best models are ARIMA $(2,1,3)$ and ARIMA $(3,1,3)$.

To compare the two models, we can compare values Akaike Info Criterion (AIC) and Schwarz Criterion (GIS). Models with smaller AIC and SIC values are of better quality, and that is the model we should choose. 


\section{Comparison of SIC and AIC values}

Table 7 Comparison Test Result of SIC and AIC Values

\begin{tabular}{|l|l|l|l|}
\hline Value & ARIMA & ARIMA & Conclusion \\
\hline AIC & 12.9062 & 12.90107 & Selected \\
\hline SIC & 12.9579 & 12.96022 & Selected \\
\hline
\end{tabular}

Source: SPSS

Since none of the AIC and SIC values give absolute better values, the next step is to test each model by calculating the standard error (standard error) of each ARIMA against the index, as follows:

\section{Comparison of Standard Errors}

Table 8. Result of Standard Error Comparison Test

\begin{tabular}{|l|c|l|}
\hline Variable & ARIMA & Standard Error(SE) \\
\hline Share Price of BNI & $2,1,3$ & 152.6424 \\
Share Price of BNI & $3,1,3$ & 151.6302 \\
\hline
\end{tabular}

Source: SPSS

And after testing by comparing the standard error values of each ARIMA, the smallest ARIMA error standard $(3,1,3)$ is obtained, it concluded that the ARIMA model $(3,1,3)$ is a model that is closer to the observation values, then the model chosen in predicting stock prices in this study is the ARIMA model $(3,1,3)$.

Based on the results of the ARIMA e-views model $(3,1,3)$, it obtained:

$\mathrm{Yt}=\mathrm{Yt}-1(1-\rho 1)+\mathrm{Yt}-2(\rho 2-\rho 1)+\mathrm{Yt}-3(\rho 3-$

$\rho 2)$ - $\rho 3 Y t-4-C+q 1 \varepsilon t-1$ - q2Et-2 - q3Et-3

$\rho 1=\operatorname{AR}(1)=-0.714721$

$\mathrm{q} 1=\mathrm{MA}(1)=0.729283$

$\rho 2=\mathrm{AR}(2)=-0.864127$

$\mathrm{q} 2=\mathrm{MA}(2)=0.845787$

$\rho 3=\operatorname{AR}(3)=-0.858083$

$\mathrm{q} 3=\mathrm{MA}(3)=0.898101$

$C=6.331988$

\section{Following}

$Y \mathrm{t}=\mathrm{Yt}-1(1-(-0.714721)+\mathrm{Yt}-2(-0.864127)-(-0.714721)+\mathrm{Yt}-3(-0.858083)-(0.864127)+(-$ 0.858083 Yt-4) $-6.331988+0.729283 \varepsilon t-1-$

$0.845787 \varepsilon t-2-0.898101 \varepsilon t-3$

Based on the calculation of the model above, the best equation model for predicting the stock price of PT. Bank Negara Indonesia (Persero) Tbk. as follow:

$\mathrm{Yt}=-6.331988+1.714721 \mathrm{Yt}-1-0.149406) \mathrm{Yt}-2-1.72221 \quad \mathrm{Yt}-3+0.858083 \mathrm{Yt}-4+$ $0.729283 \varepsilon t-10.845787 \varepsilon t-2-0.898101 \varepsilon t-3$ 


\section{Estimating}

The final step in time series analysis is to determine the forecast or prediction for the next period. In this discussion, PT Bank Negara Indonesia (Persero) Tbk. will predict the share price for the next ten days: (1). display dynamic and static graphs, (2) display the estimation of the result.

\section{Dynamic Graphing Method}

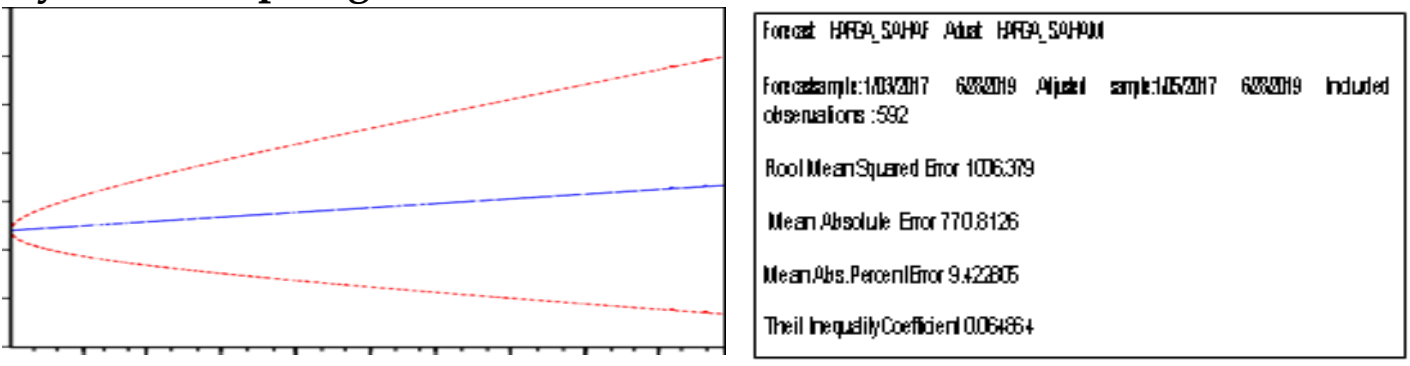

Figure 2. Dynamic Graph Method

\section{Static Graph Method}

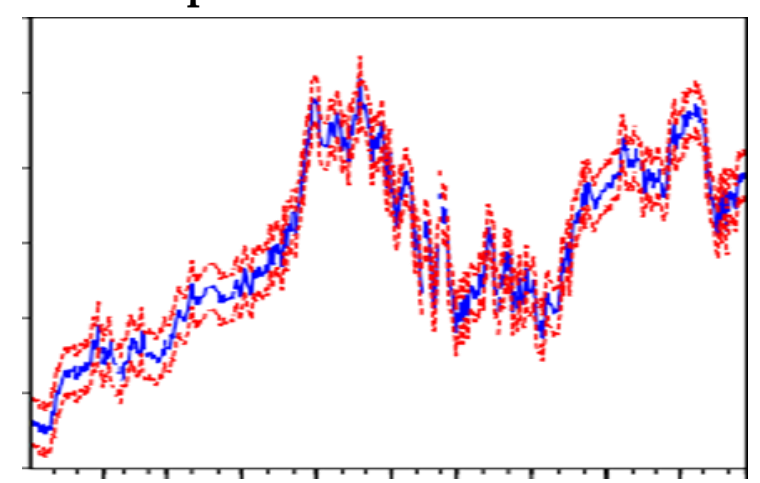

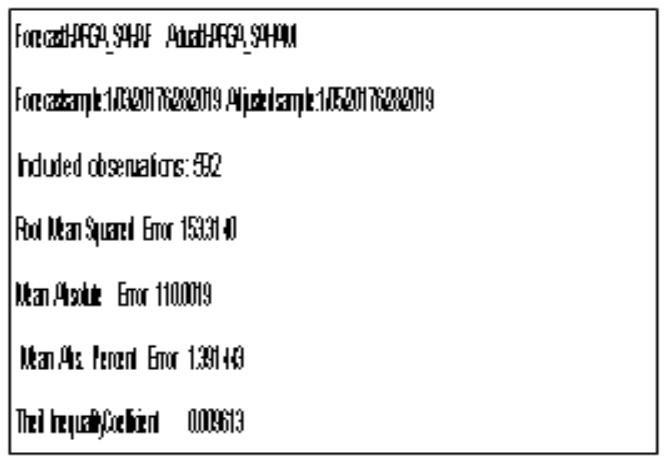

Figure 3 Static Graph Method

The different square errors are the dynamic graph method 1006,379, while the static graph method is 153,3140 . MAE and MAPE in the dynamic graph are substantial than the static graph. Also, from RMSE, MAE, and MAPE from the graph method above, it concludes that the static graph method is recommended.

\section{Estimated Value}

The estimated value displays the estimated result data in the next ten days from the research data and the actual index results. 
Table 9. Percentage of Prediction Index and Actual Index

\begin{tabular}{|l|l|l|l|}
\hline Date & Prediction Index & Actual Index & Percentage \\
\hline 1-July 2019 & 9346.53 & 9375 & $99,69 \%$ \\
\hline 2-July-2019 & 9352.23 & 9350 & $99,97 \%$ \\
\hline 3-July-2019 & 9358.52 & 9325 & $99,64 \%$ \\
\hline 4-July-2019 & 9365.46 & 9375 & $99,89 \%$ \\
\hline 5-July2019 & 9371.93 & 9200 & $98,17 \%$ \\
\hline 8-July-2019 & 9377.67 & 8975 & $95,70 \%$ \\
\hline 9-July-2019 & 9383.78 & 9150 & $97,50 \%$ \\
\hline 10-July-2019 & 9390.66 & 9150 & $97,43 \%$ \\
\hline 11-July-2019 & 9397.30 & 9250 & $98,43 \%$ \\
\hline 12-July-2019 & 9403.13 & 9200 & $97,83 \%$ \\
\hline
\end{tabular}

It interprets that the stock prediction index for the next ten days and the ten-day actual index of all the research prediction data. The purpose of this research is to try to predict stock prices in the next ten days and minimize the error rate in decision making.

\section{CONCLUSION AND SUGGESTIONS}

Based on the research result on data time-series analysis by using the Arima method ( $\mathrm{p}$, $\mathrm{d}, \mathrm{q}$ ), it concluded that the prediction of PT. Bank Negara Indonesia (Persero) Tbk. in the next is to use the ARIMA model $(3,1,3)$. It is reinforced by the ARIMA $(3,1,3)$ error standard data which is equal to 151.6302, which is the smallest error standard among all tested error standards. Based on the research conducted, the model equation is:

$\mathrm{Yt}=-6.331988+1.714721 \mathrm{Yt}-1-0.149406 \quad \mathrm{Yt}-2-1.72221 \mathrm{Yt}-3+0.858083 \mathrm{Yt}-4$

$+0.729283 \varepsilon \mathrm{t}-1-0.845787 \varepsilon \mathrm{t}-2$

$-0.898101 \varepsilon \mathrm{t}-3$

Based on research conducted at PT. Bank Negara Indonesia (Persero) Tbk., The resulting level of accuracy of the stock prediction index against the actual index for the next ten days is at $95.70 \%$ to $99.97 \%$. The results of this research also input for market players, especially in predicting future stock price fluctuations.

\section{References}

Anityaloka, R,N.,Ambarwati ,A,N.(2010). Peramalan Saham Jakarta Islamic Index Menggunakan Metode Arima Bulan Mei-Juli 2010.

Brigham.,Houston. (2010). Dasar-Dasar Manajemen Keuangan Buku 1. Edis11. Jakarta: Salemba Empat.

Darmadji.,Fakhruddin. (2012). Pasar modal di Indonesia.Salemba Empat, Jakarta.

Fahmi,I.(2012). Pengantar Pasar Modal. Bandung : Alfabeta.

Greis S. L., Hatidja,D., John S,K.(2014) .Prediksi Harga Saham PT BRI dengan menggunakan Metode ARIMA.

Hendrawan, B.(2019). Penerapan Model ARIMA Dalam Memprediksi IHSG.

Hatidja,D.(2011).Penerapan Model Arima Untuk Memprediksi Harga Saham Pt.Telkom Tbk. 
Hartono.,Jogiyanto. (2008).Teori Portofolio dan Analisis Investasi. Yogyakarta : BPFE.

Nurindah ,Erna Dwi .2017. Peramalan Harga Saham Perusahaan Industri

Pardede, P.(2016) . Penerapan Model Arima Dalam Memprediksi Indeks Harga Saham Gabungan Bursa Efek Indonesia- Jakarta.

Perbankan Menggunakan Metode Arima Box-Jenkins Nachrowi, N.

D.,Hardius,U.(2014). Penggunaan Teknuik Ekonometri: Pendekatan Populer\&Praktis, edisi revisi Jakarta: PT Raja Grasindo

Tandelilin, Eduardus. (2010). Protofolio dan Investasi: Teori dan Aplikasi. Yogyakarta: Kanisius.

Widoatmodjo, S.(2015). Pengetahuan Pasar Modal untuk Konteks Indonesia.Jakarta : Elex Media Komputindo https://www.idx.co.id/produk/saham/

https://www.sahamok.com/2016/09/22/forbes-6-perusahaan-publik-terbesar-diindonesia-2016/

https://www.investing.com/equities/bank-bni-tbk-historical-data https://id.wikipedia.org/wiki/Saham 